\title{
Editorial
}

\section{The wide world of branding}

\section{INTRODUCTION}

The majority of the papers in this Journal are about the development and protection of global brands. However, it is important to recognise that at this time most brands are not world brands at all - they are national brands that occupy a particular local niche and function only in their home markets. Such local brands fall into two categories:

- Brands which are similar to other brands in other countries in terms of formulation, function and appearance but which for various reasons - tariff barriers, established competition in overseas markets, trademark problems or lack of interest on the part of their owners are not sold outside their home markets.

- Brands which are so idiosyncratically adapted to their home markets that they are unlikely to have immediate appeal in foreign markets.

Brands which fall into this first category are by far the most common. In Britain, for example, bread is heavily branded but the major varieties are at most national in their scope. The difficulties involved in the export of fresh food, together with such factors as local tastes, largely account for the localised nature of brands in this segment.

It is clearly possible to develop large, strong and successful local brands based entirely upon local markets - indeed most brands are of this type. Such brands, however, are increasingly overshadowed by the major international brands which are seen to have more power, more appeal and are altogether more reassuring to the consumer. $\mathrm{Al}$ - though consumers support their local brands, there is an undeniable attraction to the 'big' brand, which is frequently of international or global standing.

But need local brands necessarily remain local? Does not the fact that a product is found appealing in one market tend to suggest that there could be other markets out there which might find it equally appealing? It is interesting to note that in the USA the enormous growth of ethnic foods and the general broadening of eating habits have created niche markets for many formerly local foreign products, which would have been inconceivable a few years ago. And this phenomenon is not confined. European brewers, for example, have penetrated both the USA and the UK markets with enormous success, and beer drinkers, particularly the younger and more upwardly mobile ones, have adjusted their tastes and switched to imports with increasing frequency. While trade barriers are undoubtedly a factor, one suspects that in many cases the real reason for local brands not becoming world brands is more likely to be lack of enterprise, lack of commitment and the failure to spot opportunity before it is too late.

Nevertheless, while markets draw closer together and become similar, it is important to continue to be aware of national particularities. Often, it is found that national caricatures contain more than a grain of truth - brash Americans, conservative Englishmen, unco-operative French, volatile Italians, pedantic Germans and unfathomable Japanese - and in branding it is necessary to see clearly the differences as well as the similarities. 


\section{THE AMERICAN APPROACH TO BRANDING}

With 250 million increasingly wealthy consumers, the USA frequently represents one half or more of the world's potential for any branded product. It is not surprising, therefore, that US corporations have tended in the past to focus almost exclusively on their home market. During the 1950s and 1960s this corporate myopia cost American industry little. Western Europe, for example, was struggling to emerge from the devastation of the war. Add to this scenario the wide variety of cultures, languages and governments and it is not surprising that for many US companies Western Europe was not an especially inviting market.

Nor did the Far East appear particularly attractive. Per capita incomes were low, tastes were radically different and in many cases unsophisticated, and the abilities of governments in the region to put roadblocks in the way of Western businesses were legendary.

As a consequence, there was a strong tendency on the part of American companies to concern themselves simply with their own domestic market. As far as branding is concerned, this manifested itself in a peculiarly American approach, the essence of which is directness - even bluntness.

American branding philosophy required that the brand owner get to the point as quickly as possible. Subtlety, style and gentle persuasion took a back seat to getting the message across with maximum impact, speed and efficiency. Given the sheer physical size of the US market, the enormous number of competing products and the awesome cost involved in reaching a target market of any appreciable size, this approach to branding is understandable and, probably, appropriate. Furthermore, trademark law in the US allowed, and still allows, companies to protect such highly direct and even descriptive brands as, for example, Dial-a-Lash for mascara, Lite for beer and HandiWrap for a food wrapping product.
The drawbacks of this approach to branding began to manifest themselves when international markets entered the picture. The US brand names frequently proved to be too descriptive to be readily protected in certain countries, for example the UK or Germany, too lacking in subtlety and emotional values in others, for example France and Italy, and culturally unacceptable or impossible to pronounce in others.

In a sense, the American approach at times matches the national caricature and American corporations are frequently much less international in their outlook and much less sensitive in their approach to international branding than their size and the scale of their international operations might suggest.

\section{THE JAPANESE APPROACH}

The Japanese consumer is perfectly happy to eat Claps chips and Melty Kiss chocolate, while drinking Blendy coffee laced with Creap non-dairy creamer. He uses Naive shampoo and puts Skinababe cream on the baby's bottom. He eats at restaurants with names like Ducky Duck and La Derriere, and drives a Big Thumb truck. The branding vocabulary in Japan is in a class by itself.

The Japanese term for words borrowed from other languages is gairaigo: the language has thousands of these borrowings, and adds hundreds more each year. Mostly derived from English, gairaigo has proven it can really move the merchandise. They get attached to cars and soft drinks and toiletries with an exuberance unmatched anywhere in the world.

The use of gairaigo is not a recent trend. Foreign goods had traditionally been perceived as having a distinct cachet, and by extension, any product with a foreign name came to have a special appeal, a mystique, an implied presumption of quality. Although most Japanese products today are equal or superior in quality to goods from overseas, foreign language brand names have lost none of their appeal or mystique. 
One reason why Japanese companies frequently prefer foreign language brand names is practicality. The Japanese language has three different written forms - Kanji, with its several thousand Chinese characters, and two phonetic systems, Hiragana and Katakana, with approximately 50 symbols in each. Katakana is used for words of foreign derivation and products with a foreign name normally carry the Katakana transliteration. Even at the most basic level, Japanese must know approximately 2,000 Kanji characters, and each character has several different pronunciations. Hence the use of Kanji can result in extreme confusion as to the pronunciation of the name, and thus the use of foreign names in their Katakana transliteration ensures that this will not be a problem.

A problem that does continue to plague Japanese manufacturers, however, is how to accommodate the vastly different branding requirements of the domestic and overseas markets. Despite the high visibility of Japanese products in world markets, it is the domestic market that continues to be of paramount importance. Products are almost always launched in the domestic market first, and those that succeed are then taken overseas. It is often at this point that problems with brand names first appear. Lack of originality often means that the name is unavailable in the markets of interest. Those that are available are frequently so idiosyncratic as to be unusable.

Pocari Sweat is a sports drink that was launched in the Japanese market in 1980 and soon became hugely popular. Obviously to the Japanese, there was nothing particularly unusual in drinking a beverage called Sweat after a workout. When test-marketed overseas, however, the response was predictable and ranged from hilarity to repulsion. Reluctantly, the name was changed and the product is marketed overseas as Pocari.

The challenge for Japanese companies in the future will be to identify those products which are likely to be marketed overseas at an earlier stage in their development, and to develop branding strategies that fully consider the diverse requirements of both the domestic and the overseas markets, allowing them to function and compete effectively in both.

\section{THE EUROPEAN APPROACH}

The major Western European countries have, over the past 20 years, provided us with the ideal laboratory in which to view the gradual move from a primarily domestic or national focus to one that is increasingly international.

European companies have traditionally been quite insular and nationalistic, and these traits have clearly manifested themselves in their approach to branding. Gradually, however, the countries and companies of Western Europe have been forced to adopt a wider perspective, eventually shifting towards an environment that encouraged companies to favor a global perspective over a national one. In this respect they are probably still behind the Japanese, who understood much earlier that they must export and develop world markets in order to survive, but they are ahead of the Americans, who have been slow in developing a global approach simply because they have the world's richest market quite literally in their own backyard.

In spite of this trend towards globalisation, it is interesting to note that relatively few Eurobrands lead their segments in multiple European markets, though examples of highly successful international brands which are segment leaders in multiple European markets include Nescafé instant coffee, Colgate toothpaste, Marlboro cigarettes, Avon cosmetics, and Schweppes mixers. European markets thus tend to be populated by a mix of European and global brands on the one hand, and brands which are peculiarly and determinedly national on the other. This situation is likely to continue, although clearly those companies prepared to develop 
brands that can appeal across national, cultural and language barriers are the ones likely to gain the most in the long term.

\section{CONCLUSIONS}

We have tried to illustrate how certain key markets have gone about branding at the national level, and what has been done to expand these basic approaches into the international arena.

We by no means advocate the abandonment of a local approach to branding; indeed, it is the richness of our national cultural experiences which adds immeasurable value and texture to our products. But if there is a lesson for all of us, it is that successful and effective branding implies a sensitivity, not only to our own local requirements, but increasingly to those of other markets to whom we wish to appeal. Sometimes our products may succeed precisely because of their idiosyncrasies, for it is these that give them their distinctiveness and appeal. And, sometimes, they may succeed despite their idiosyncrasies. But whatever the case, we as developers of brands should be keenly aware of national differences and should develop our brands from the outset to take these into account.

\section{Terence Oliver Editorial Board}

